\title{
Disneyland-epidemien - kan det samme skje i Norge?
}

\author{
De senere års meslingepidemier har vist at sykdommen er langt fra utryddet, heller ikke i den vestlige \\ verden. Fallende vaksinasjonsdekning truer flokkimmuniteten og gjør at viruset kan spre seg i befolkningen. \\ Og hvor varig er egentlig den immuniteten som vaksinen gir?
}

I år 2000 erklærte amerikanske helsemyndigheter meslinger for utryddet i USA (1). Da hadde det i flere år bare vært registrert spredte, importerte tilfeller av sykdommen, færre enn 100 tilfeller årlig. Det laveste antallet ble registrert i 2004 - bare 37 tilfeller.

De to siste årene har vist at det var for tidlig å trekke en slik konklusjon. I 2014 ble det rapportert 644 nye tilfeller av meslinger i USA (2), og i de tre første månedene av 2015 har det vært påvist 159 nye tilfeller, hvorav 111 med utgangspunkt $i$ en tilreisende meslingsyk som besøkte Disneyland i California (3). I løpet av kort tid spredte epidemien seg til i alt sju amerikanske delstater og til nabolandene Canada og Mexico (4).

Totalt sett er verden meget langt fra å være fri for meslingsmitte. Også i Europa er det utbrudd i mange land. Verdens helseorganisasjon (WHO) registrerte over 22000 tilfeller av meslinger i denne verdensdelen i perioden 1.1. 2014-25.2. 2015, de aller fleste $i$ land med lav vaksinasjonsdekning (5).

Forekomsten i utviklingsland er likevel av en helt annen størrelsesorden, og sykdommen er blitt en av mange indikatorer på forskjellen mellom rike og fattige land. Ifølge det amerikanske Centers for Disease Control and Prevention (CDC) oppstår det fortsatt 20 millioner nye tilfeller av meslinger årlig på verdensbasis (6), og 145700 døde av sykdommen eller dens komplikasjoner i 2013 (7).

\section{Hvorfor er meslinger så vanskelig å bli kvitt?}

Noe av forklaringen er den enormt høye smittsomheten av meslinger. Den epidemiologiske konstanten $\mathrm{R}_{0}$ uttrykker hvor mange nye tilfeller ett enkelt tilfelle av en infeksjonssykdom gir opphav til. Med en $\mathrm{R}_{0}$ på mellom 12 og 18 er meslinger den mest smittsomme sykdommen vi kjenner $\left(\mathrm{R}_{0}\right.$ for kopper var til sammenlikning 6 , for ebola er den $1,5-2,5)(2,8)$.

I en fullt mottakelig befolkning vil over $90 \%$ bli syke dersom de utsettes for meslingsmitte (8). Derfor kreves det høy vaksinasjonsdekning med en effektiv vaksine for å oppnå flokkimmunitet. Ved flokkimmunitet kan viruset ikke lenger spre seg i befolkningen - de mange immune individene beskytter de få gjenværende mottakelige fra å bli smittet, med mindre de sistnevnte er så uheldige å komme i direkte kontakt med en meslingsyk person. Slik kontakt skjer gjerne ved at de reiser til eller kommer $i$ kontakt med noen fra et land der meslinger fortsatt er vanlig.

Terskelen for flokkimmunitet $(\mathrm{F})$ er bestemt av likningen $F=1-\left(1 / R_{0}\right)(8)$.

Med en $\mathrm{R}_{0}$ på 15 kreves det ved meslinger at $93,3 \%$ av befolkningen er immune for å oppnå flokkimmunitet. Den MMR-vaksinen som er i bruk, er oppgitt å gi ca. $93 \%$ beskyttelse etter én dose og ca. $97 \%$ beskyttelse etter to (9). Forutsetter vi at alle vaksineres med to doser, vil det kreves en vak-

\section{«Det kan tyde på at MMR-vaksinen ikke gir så høy beskyttelse som den rene mesling- vaksinen»}

sinasjonsdekning på over $96 \%$ for å oppnå full flokkimmunitet mot meslinger. Vaksinasjonsdekningen for MMR-vaksinen i Norge lå ifølge Nasjonalt vaksinasjonsregister (SYSVAK) i 2012 på 94,4\% (10). Kan vi da føle oss trygge?

Tall fra Centers for Disease Control and Prevention viser at i 2013 var den estimerte dekningen med minst én dose MMR-vaksine for barn i alderen 19-35 måneder 91,7 \% i USA sett under ett. I California, der det aktuelle utbruddet startet, var dekningen $90,7 \%$, og i de andre statene varierte estimert dekning fra ned mot $86 \%$ til opp mot $96 \%$. For tenåringer i alderen $13-17$ år er tallene for dekning med to doser omtrent lik, henholdsvis $91,8 \%$ for USA og $91,5 \%$ for California, og med en tilsvarende variasjon fra stat til stat $(11,12)$.

Når vaksinasjon får sykdommen til å forsvinne fra folks bevissthet, vil det erfaringsmessig bli vanskeligere å opprettholde en høy vaksinasjonsdekning, og selv relativt beskjedne bivirkninger kan da føre til dårligere oppslutning om vaksinasjonsprogrammet. Man kan da tenke seg at påstander om alvorlige bivirkninger, slik det feilaktig har vært anført om MMR-vaksinen, sannsynligvis vil føre til alvorlig svikt $i$ oppslutningen.
I tillegg er det et problem at vaksinasjonsdekningen har vært ujevn, med lavere dekning i enkelte miljøer. Bare i California er det estimert at over 13000 barnehagebarn er uvaksinert av «personlige eller religiøse grunner» (13). Dersom estimatene for vaksinasjonsdekningen i California er korrekte, viser det aktuelle utbruddet at $91 \%$ dekning med to doser MMR-vaksine ikke er tilstrekkelig til å oppnå effektiv flokkimmunitet.

Vår vaksinasjonsdekning ligger altså noe høyere på landsbasis, men i fylker som Oslo og Vestfold er den ifølge SYSVAK ikke særlig høyere enn i California (hhv. $92,7 \%$ og 92,9\%) (10). Det er derfor grunn til å vurdere tiltak som kan øke dekningen av vaksinen, spesielt i de fylkene som henger etter.

\section{Lavere beskyttelse enn antatt?}

Det er likevel en annen side ved Disneyland-epidemien som også bør kommenteres. Av 110 tilfeller registrert i California frem til medio februar 2015, var det 62 som hadde dokumenterbar vaksinasjonsstatus. Av disse igjen var 49 uvaksinert, fem hadde fått én dose, sju hadde fått to doser og én hadde fått tre doser MMR-vaksine (4).

At hele 13 av $62(20 \%)$ av tilfellene hos dem med kjent vaksinasjonsstatus oppsto blant vaksinerte, kan virke foruroligende. Det kan tyde på at MMR-vaksinen, som for å gjøre den mer akseptabel - inneholder ytterligere svekket meslingvirus, ikke gir så høy beskyttelse som den rene meslingvaksinen som ble innført i Norge i 1968. Den inneholdt et mer virulent virus. Eller det kan være slik at immuniteten svinner over tid $(14,15)$ ?

I en fersk rapport fra april 2015 berettes det om totalt 159 meslingtilfeller i USA, hvorav 111 var tilknyttet Disneyland-epidemien. Av de 159 syke hadde 28 (18 \%) fått én eller to doser MMR-vaksine (3). Her må man imidlertid huske på at i en befolkning med en vaksinasjonsdekning på ca. $90 \%$ vil det, med en jevn distribusjon av uvaksinerte individer i befolkningen, være nærmere ti ganger så mange vaksinerte som uvaksinerte som er blitt eksponert for smitte under et utbrudd.

I den siste rapporten fra USA var det 71 uvaksinerte blant dem med kjent vaksinasjonsstatus som ble syke. Sannsynligvis var det da godt over 700 vaksinerte som var blitt 
eksponert for smitte. Postulerer vi at 800 vaksinerte var blitt utsatt for smitte, ville man forvente at 24 ville få meslinger dersom MMR-vaksinen gir $97 \%$ beskyttelse, 16 dersom beskyttelsesgraden er $98 \%$.

Det knytter seg likevel usikkerhet til hvor mange av de 60 med ukjent vaksinasjonsstatus som hadde fått én eller to doser MMR-vaksine. Alderen på de vaksinerte som ble syke er ikke opplyst, men aldersspennet blant meslingtilfellene var 6 uker70 år, hvorav $55 \%$ var over 20 år, slik at det kan ha gått atskillig tid fra vaksinasjon til smittetidspunkt (3)

Hvis det skulle vise seg at den MMRinduserte immuniteten ikke er stabil over tid hos en viss andel av de vaksinerte, kan vi ikke lenger stole på vaksinasjonsdekningen som et mål for immuniteten i befolkningen. Uansett mener jeg tallene fra USA er en påminnelse om at MMR-vaksinasjon, enten det er med én eller to doser, ikke gir beskyttelse for alle, og at vaksinasjonsdekningen bør være på mellom $96 \%$ og $97 \%$ for å oppnå sikker flokkimmunitet i befolkningen.

Takket være vårt vaksinasjonsregister SYSVAK har vi i Norge full oversikt over vaksinasjonsdekningen. Oversikten over befolkningens immunstatus er imidlertid ikke like god, i og med at erfaringene fra USA viser at man ikke kan sette likhetstegn mellom MMR-vaksinasjon og immunitet mot meslinger. Jeg mener derfor at man snarest burde kartlegge immunstatus i befolkningen ved å måle meslingantistoffer i serum hos et representativt utvalg av ulike alderskohorter (16). Dersom antistoffnivåene skulle vise tendens til å avta med tid etter vaksinasjon, bør situasjonen overvåkes nøye. Uansett bør man vurdere om det er behov for ytterligere vaksinasjon for å oppnå en betryggende flokkimmunitet, slik at vi unngår at også vi får en Disneyland-epidemi.

Otto Closs

otto.closs@getmail.no

Otto Closs (f. 1938) er dr.med., spesialist i medisinsk mikrobiologi og har en mastergrad i Public Health. Som pensjonist er han deltidsengasjert som seniorrådgiver ved Helseavdelingen, Fylkesmannen i Oslo og Akershus. Han har arbeidet med forskning innen infeksjonsimmunologi og med vaksineproduksjon og vaksineforsyning.

Forfatter har fylt ut ICMJE-skjemaet og oppgir ingen interessekonflikter.
Litteratur

1. Katz SL, Hinman AR. Summary and conclusions: measles elimination meeting, 16-17 March 2000 J Infect Dis 2004; 189 (suppl 1): S43-7.

2. ProMED-mail Measles update 08. 22.2.2015. www.promedmail.org/ (5.5.2015).

3. Clemmons NS, Gastanaduy PA, Fiebelkorn AP et al. Measles - United States, January 4-April 2, 2015. MMWR Morbid Mortal Wkly Rep 2015; 64: $373-6$

4. Zipprich J, Winter K, Hacker J et al. Measles outbreak-California, December 2014-February 2015. MMWR Morb Mortal Wkly Rep 2015; 64: $153-4$

5. WHO/Europe calls for scaled-up vaccination against measles. København 25.2.2015. www.euro.who.int/en/media-centre/sections/ press-releases/2015/whoeurope-calls-for-scaledup-vaccination-against-measles (5.5.2015).

6. Centers for Disease Control and Prevention. Information for travelers. http://wwwnc.cdc.gov/travel (5.5.2015).

7. WHO. Measles. WHO Fact sheet No 286. Februar 2015. www.who.int/mediacentre/factsheets/fs286/ en/ (5.5.2015)

8. Fine PEM. Herd immunity: history, theory, practice. Epidemiol Rev 1993; 15: 265-302.

9. Centers for Disease Control and Prevention. Measles (Rubeola). www.cdc.gov/measles/ vaccination.html (27.4.2015)

10. Nasjonalt vaksinasjonsregister (SYSVAK). Vaksinasjonsdekning - MMR-vaksine, andel (prosent). www. fhi.no/eway/default.aspx? pid=239\&trg=List 6212\&Main_6157=6263:0:25,6566\&MainContent $6263=6464: 0: 25,7072 \&$ List_6212 $=6218: 0: 25,7861$ : 1:0:0:0:0 (5.5.2015)

11. Elam-Evans LD, Yankey D et al. National, state and selected local area vaccination coverage among children aged 19-35 months - United States 2013. MMWR Morbid Mortal Wkly Rep 2014 63: 741-8.

12. Elam-Evans LD, Yankey D, Jeyarajah J et al. National, regional, state, and selected local area vaccination coverage among adolescents aged 13-17 years - United States, 2013. MMWR Morb Mortal Wkly Rep 2014: 63: 625-33.

13. ProMED-mail. Measles update 06. 10.2.2015 http://promedmail.chip.org/pipermail/promedweekly-update/2015-February/000142.html (5.5.2015).

14. Ishimura S, Morishima T, Nishikawa K et al. A long-term follow-up study on the efficacy of further attenuated live measles vaccine. Biken CAM vaccine. Biken J 1986; 29: 19-26.

15. Markowitz LE, Katz SL. Measles vaccine. I: Plotkin SA, Mortimer EA, red. Vaccines. Philadelphia, PA: Saunders, 1994: 229-76.

16. Closs 0. Should measles be eradicated? On the significance of subclinical measles virus infection in the vaccine era. Avhandling för Master of Public Health. Göteborg: Nordiska Hälsovårdshögskolan, 2001: $46-7$.

Mottatt 30.3. 2015, første revisjon innsendt 23.4. 2015, godkjent 4.5. 2015. Redaktør: Lise Mørkved Helsingen.

Publisert først på nett. 